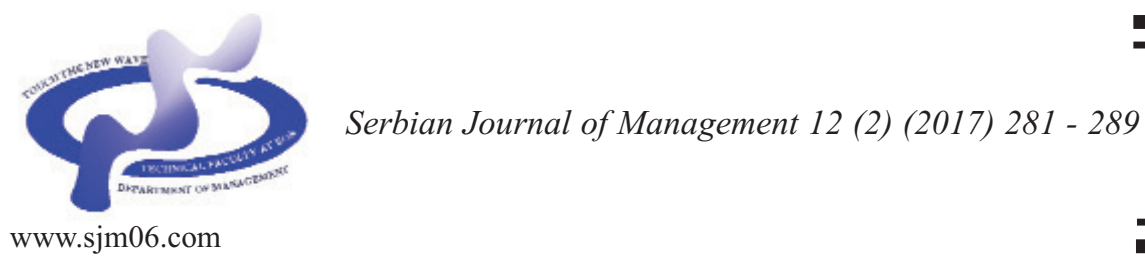

\title{
PREDICTION AND ANALYSIS OF SLOVAKIAN TIMBER TRADE ON GLOBAL MARKET CONDITIONS
}

\author{
Miloš Gejdoša and Marek Potkány $\mathbf{b}^{*}$

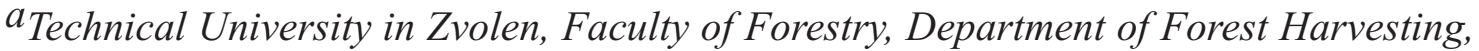 \\ Logistics and Ameliorations, T. G. Masaryka 24, Zvolen 960 53, Slovakia \\ ${ }^{b}$ Technical University in Zvolen, Faculty of Wood Sciences and Technology, Department of \\ Business Economics, T. G. Masaryka 24, Zvolen 960 53, Slovakia \\ (Received 10 June 2017; accepted 16 September 2017)
}

\begin{abstract}
In Slovakian forestry the main source of finance is the wood sale. The main aim of this paper is to evaluate the assortments supply structure (quality management), prices development for the coniferous sawlogs and to set the future prediction of this development in new global market conditions, which are affected mainly by the global climate changes. Price changes were analysed for the period of the years from 2000 to March 2016 for the spruce and fir sawlogs. Data about the volume supply of raw-wood assortments in Slovakia for years 2005-2014 were collected from "Green Reports" published by the Ministry of Agriculture and Rural Development of the Slovak Republic. From the influence factors in the studied period, the biggest impact was assigned to the global economic crisis. The prediction captures the further decline of prices of raw-wood assortments. In the second half of the year 2016 the price of sawlogs decreased by $€ 4$ per $1 \mathrm{~m} 3$. Local impacts, the structure of wood processors and specific trade area in Slovakia affected substantially the structure of assortments on Market. There is also some space for a better evaluation of harvested wood.
\end{abstract}

Keywords: Raw-wood assortments, timber market, wood prices, supplies of wood

\section{INTRODUCTION}

Timber market with wood and the wood products is the main area of interest for wood producers and wood-processing industry. In Slovakian forestry the main source of finance is the wood sale. The state market, the European and the global market influence each other. The timber market and trade with wood is affected by several main factors (global climate change - increasing volume of incidental felling, global

\footnotetext{
* Corresponding author:
}

DOI: $10.5937 /$ sjm12-11228 
economic crisis - decreasing consumption of the timber products, prices of fossil fuels, geopolitical situation). These factors have mainly global impact on the global and European markets. For the right orientation on the market with wood and for setting the marketing strategy it is necessary to monitor the prices development in the global and European area. Only few forestry subjects and wood producers in Slovakia realize these facts (Suchomel et al., 2012).

Prices of raw wood and wood products are created on the basis of free market principles. Market prices are created following the economic principles and are formed basically according to the supply and demand.

In the last decade the situation on the timber market was complicated due to some factors, mainly the increasing intensity of incidental felling (due to the biotic and abiotic harmful factors). In the period of the last 20 years the intensity and volume of windthrow calamities has increased, due to the global climate change. It is a significant sign into the future that the intensity of incidental felling, due to the abiotic harmful factors, can by a serious problem for the forest ecosystems and for the wood markets. For more than 150 years, since the beginning of the industrialization in the second half of the eighteenth century, the industrialized countries have been emitting more climatedamaging carbon dioxide than the atmosphere can cope with (Hinsch \& Wächter, 2014).

Successful timber trade and average timber prices are influenced mainly by the technical standards or national rules used in timber trading. The current condition in the area of technical standards in Slovakia is relatively complicated. There are two main groups of standards (first: standards which qualitatively classify the assortments for which the use is known, second: standards which qualitatively classify the assortments for which the use is not known- European standards). According to the current law status the trade with wood can be carried out under conditions which are confirmed in contracts by seller and buyer. Many subjects use also their own rules and standards in trade. This fact makes the timber market partially unclear because the same qualitative classes cannot be compared (Suchomel \& Gejdoš, 2008; 2009). In addition to the environmental factors, affecting European and global market, there are certain regional specificities, which are typical for the Slovak, or Czech market (monopoly position of state enterprises, political influence, lobbying pressures, and lack of transparency in trade etc.) (Gejdoš et al., 2011; Grladinović et al., 2007; Teplická et al., 2015; Grzegorzewska \& StasiakBetlejewska, 2015).

The state subject Lesy SR has the dominant position on the Slovak timber market. It manages about $50 \%$ of forests in Slovakia. The company is the price leader on the market and essentially sets the baseline for the prices of raw-wood assortments and also decides about the majority of wood supply.

Up to $90 \%$ of all wood processors in Slovakia are focused on processing of coniferous sawlogs. The companies in the Association of Wood Processors (more than 140) process up to $74 \%\left(860.000 \mathrm{~m}^{3}\right)$ of these assortments. Only $23 \%$ of the supply of this processed volume comes from Lesy SR, state enterprise (Patráš, 2015).

The main aim of this paper is to evaluate the assortment supply structure (quality management), price development of the coniferous sawlogs and setting the future 
prediction of this development. Results can be used for the strategic management in enterprises of the forest producers and also wood processors. The marketing strategy is planned from the results and information about the market development (prices, volumes etc.). Information about the wood supplies and quality are also important for the planning of harvesting time and setting up the price levels on the market with wood.

\section{MATERIALS AND METHODS}

The analysed period for the price changes represented years from 2000 to March 2016 for the wood species spruce and fir in quality sawlogs, for the selected provinces of Austria, Slovakia and the Czech Republic. The Czech Republic and Austria are the main partners in the area of market with timber and raw-wood assortments. Prices in Slovakia from time period 2000 - 2008 were set in Slovak crowns for cubic meter. For comparison with other countries these prices were recalculated with the average monthly exchange rates - source National Bank of Slovakia (www.nbs.sk). The Czech prices for the same period was in Czech crowns for cubic meter. For recalculation the average monthly exchange rate of Czech national bank (www.cnb.cz) was used. The trade parities in Slovakia and the Czech Republic are different from Austria. In Slovakia and the Czech Republic it is FCA parity (according to Incoterms) and in Austria the wood is traded mainly on Forest road or Forest warehouse. For the comparison it is necessary to add the transportation costs to Austrian prices $\left(7 € . \mathrm{m}^{-3}\right)$.

Data for the prices development analysis in Austria were obtained from Holzkurier Austrian journal, in Slovakia form Forest
Market

Information

System

(www.forestportal.sk) and in the Czech Republic from the Czech Statistical Office (www.czso.cz).

Data about the volume supply of rawwood assortments in Slovakia for years 2005-2014 were obtained from "Green reports" published by the Ministry of Agriculture and Rural Development of the Slovak Republic.

For predicting the price development of selected raw-wood assortments and development of assortment structure in the future, the method of smoothing the time series data with moving averages was used. Cipra (1986) defined this method for the time series prediction as highly valuable, with good results. For this analysis the Software STATISTICA 12.0 was used.

\section{RESULTS}

Figures 1 and 2 show the supplies volume development of coniferous and nonconiferous raw-wood assortments in Slovakia, which have the largest market share. Data for 2015 have not been available yet. The figure 1 shows, that between 2008 and 2009, the share of coniferous sawlogs supply decreased and the share of fibre wood supply increased. The main reasons for this development are the global economic crisis and the increasing pressure of customers on the quality of raw wood material. In the period of the global economic crisis the high quality raw wood was commonly purchased as saw logs. Excessive supply over demand had the dominant influence in this period.

The main standards STN 480055 and 48 0056 were also revised in 2007 . This revision modified the technical conditions for the assortments production and reduced the 


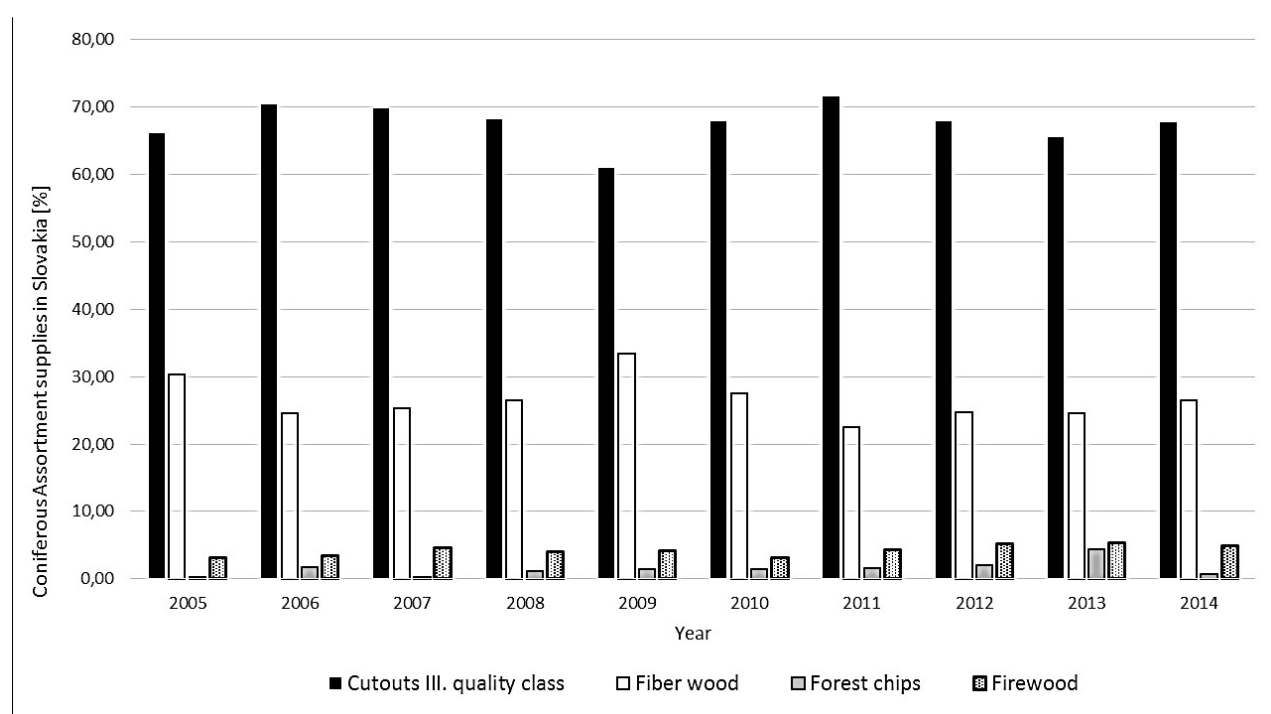

Figure 1. Supply structure of selected coniferous raw-wood assortments in Slovakia [\% of volume] (Source:Green report 2005-2015)

technical potential for production of the best felling caused by winds and bark beetles, but quality raw wood assortments. In the last also from the long-term contracts (up to year three years there was a noticeable decline in 2017) signed by the enterprise Lesy SR and the supply of fibre wood, from which a part subjects that in fact do not process any wood. of the volume is processed as sawn wood. In the supply of non-coniferous This has resulted from the reduction in the assortments, the fibre-wood assortment has planned logging, following the incidental the biggest share. The share of supply of

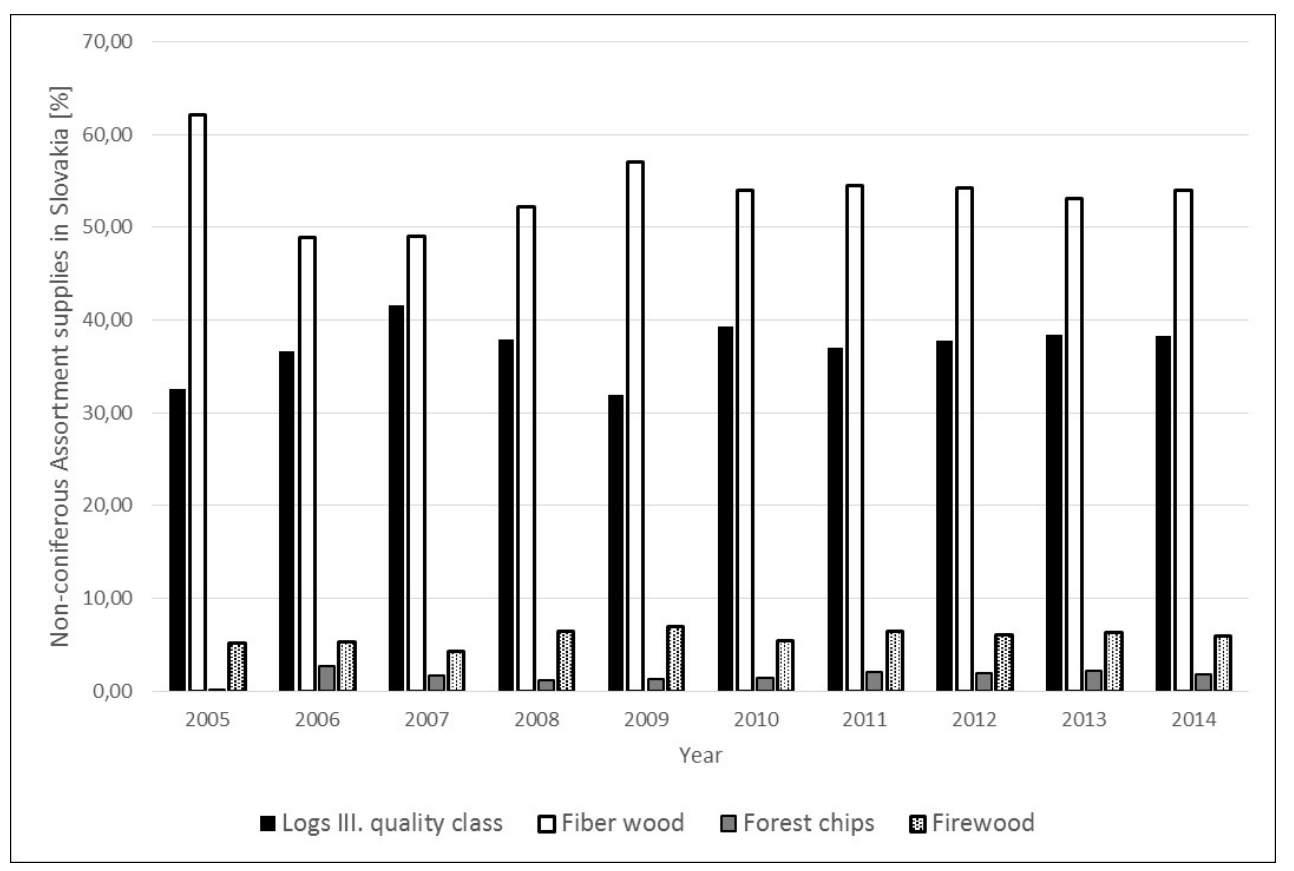

Figure 2. Supply structure of selected non-coniferous raw-wood assortments in Slovakia [\% of volume] (Source: Green report 2005-2015) 
non-coniferous sawlogs from 2007 did not exceed the level of $40 \%$. This situation is partly affected by the structure of the wood processing industry in Slovakia and generally in the whole Europe and world by the low demand for sawn wood products from beech wood (beech has the biggest share in the Slovak forests). The share of non-coniferous assortments supply for energy use is relatively stable, in the long term. Part of the heat producers purchase the assortments which are assigned for being processed by the cellulosic-paper industry (fibre wood) and are able to pay higher purchase prices.

Figure 3 shows prices development for the spruce and fir sawlogs assortments in Slovakia (average price for subclasses A, B, C), Czech Republic and selected provinces of Austria. The period 2000-2007 was relatively stable. Year 2007 was in practice marked as the "golden age" for the wood processing industry, with the highest increasing timber prices and volume of timber products consumption. After the beginning of 2008 and 2009 (impact of global economic crisis) Austria recorded a significant price decrease. The most significant decline of sawlogs assortments prices (subclasses $\mathrm{A} / \mathrm{B} / \mathrm{C}$ ) was recorded in Burgenland. For the first three months in 2008 the decrease was around $13 € . \mathrm{m}^{-3}$ $(16 \%)$. The decline in Austria was caused mainly by wind calamities at the beginning of 2008. All these facts made the situation in wood resources more complicated for the wood-processing industry. At the beginning of 2009 the sawlogs prices were in all countries influenced by global recession. In the second half of 2009, there was a significant price increase in all Austrian provinces. Sawlog prices reached their maximum in April 2015 (Burgenland $96 € . m$ -3 , East Styria $95.5 € . \mathrm{m}^{-3}$, Lower Austria 103 $\left.€ . \mathrm{m}^{-3}\right)$. By the end of 2015 all prices slightly fell.

In Slovakia the prices for this assortment increased slightly in the first quarter of 2008. The total decrease during the first three months was less dramatic, in comparison

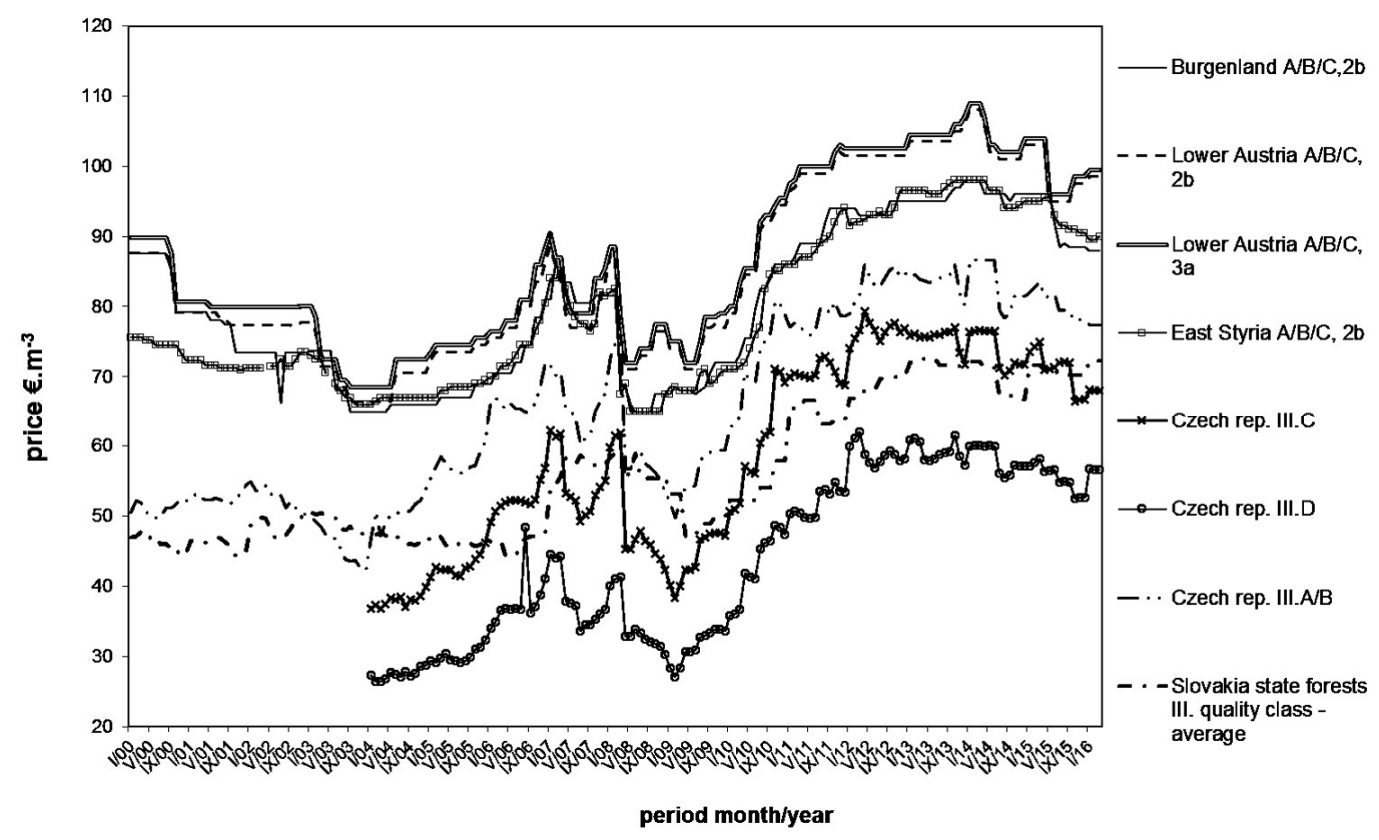

Figure 3. Changes in spruce and fir sawlog prices in Austria, Slovakia and Czech Republic [€. $m^{-3}$ ] 
with Austrian provinces. The highest decrease was for the III.A quality subclass (total fall for this assortment was $8.89 € . \mathrm{m}^{-3}$ ). After this period in the second half 2008 the price increased again, and reached total value of $74.8 € . \mathrm{m}^{-3}$. One reason for this slightly increase was the strengthening of the Slovak crown against the Euro exchange rate. In the time period of the global economic crisis (2009) the prices increased in the following subclasses: III.A - $24 \%$; III.B - $18.6 \%$, III.C $\quad 12 \%$. The biggest price increase in Slovakia was recorded in years 2011 and 2013.

In the first quarter of 2008, the prices for coniferous sawlogs were increasing slightly in the Czech Republic, influenced by the exchange rate between the Czech crown and Euro. In the second quarter a price decrease was identified (more significant than in Slovakia). In mixed quality subclass of sawlogs, III.A/B, the total decrease was 24.5 $\%\left(18.4 € . \mathrm{m}^{-3}\right)$. In quality subclass III.C the total decrease was $26.8 \%\left(16.6 € . \mathrm{m}^{-3}\right)$. In quality subclass III.D the decrease was smallest $20.8 \%\left(8.6 € \cdot \mathrm{m}^{-3}\right)$. Downward price trend in the Czech Republic was being recorded until February 2009, when sawlog prices reached their minimum (mixed subclass III.A/B $49.7 € . \mathrm{m}^{-3}$; subclass III.C $38.3 € . \mathrm{m}^{-3}$ and subclass III.D $27.1 € . \mathrm{m}^{-3}$ ). This period was followed by the increasing trend for the sawlog prices and then prices reached their maximum in March 2014 (III.A/B $86.7 € . \mathrm{m}^{-3}$ ).

From Figure 3 it is clear that the trends of wood price developments in the Central Europe are almost identical. The global economic crisis influenced the prices most significantly in the studied period. For predicting the price development in Slovakia, for the year 2016, we have used data about prices assortment quality class
III.A saw logs of spruce and fir trees in the state forests. These prices are basis for the development of all other prices of assortments in the lower quality classes.

Regression analysis confirmed that about $73 \%$ of the variance in price is explained by the price trend and the remaining $26 \%$ is caused by the variability of seasonal and random fluctuations (Table 1).

Table 1. Regression Statistics of the III.A assortment prices in Slovakia (state forests)

\begin{tabular}{lr}
\hline \multicolumn{2}{c}{ Regression Statistics } \\
\hline Multiple R & 0.859757 \\
R Square & 0.739182 \\
Adjusted R Square & 0.737741 \\
Standard Error & 4.850352 \\
Observations & 183 \\
\hline
\end{tabular}

For predicting the price development in 2016, we used the exponential moving averages with forecast for 12 months. The results of the prediction are in Figure 4.

The prediction captures the further decline in prices of raw-wood assortments. In the second half of the year 2016 the price of sawlogs should decrease by $4 €$ per $1 \mathrm{~m}^{3}$. Tendencies of this development are also confirmed by known information about the prices from some provinces in Austria, where sawlogs prices decreased by $1.5 € . \mathrm{m}^{-3}$ in April. Generally, the used prediction model makes a good prognosis for the possible future wood price development.

\section{DISCUSSION AND CONCLUSION}

Market with timber and raw-wood assortments prices are influenced by many factors. Global economic crisis, global climate change and increasing volume of incidental felling caused by biotic and 


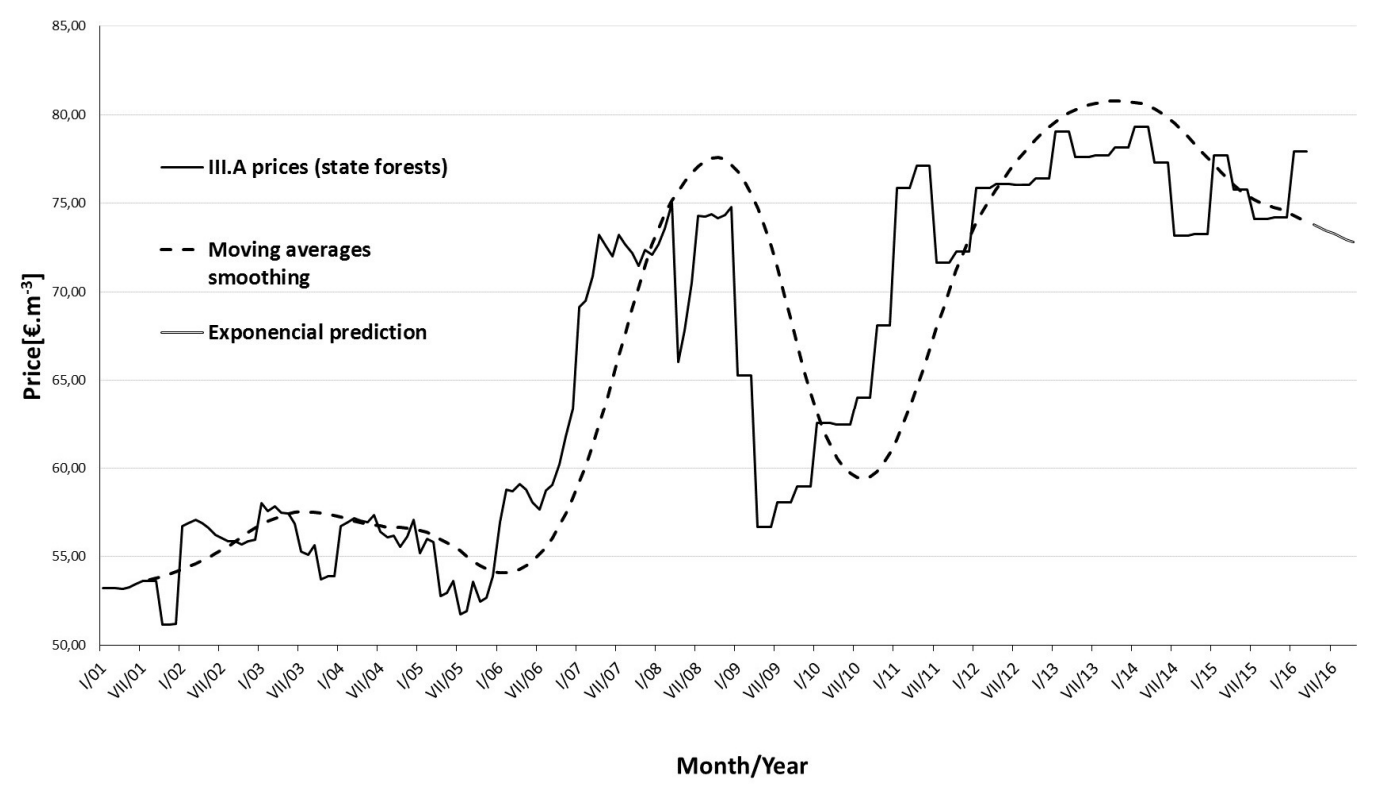

Figure 4. Prices development and prediction for 2016 of saw-log assortment, quality class III.A in Slovakia, state forests (in $€ . \mathrm{m}^{-3}$ )

abiotic harmful factors have been the main factors affecting the timber trade for the last decade. The largest incidental fellings are connected mainly with the big volume of roundwood on the market. In most cases this fact caused a decrease in the timber prices. For the future, the energy sector with wood for energy purposes will be the most stable market because the interest and consumption of renewable sources based on wood has an increasing trend. According to Simanov (2009) this increasing trend results from the EU policies for renewable energy sources. These facts at this time cause the market competition between fuelwood and industrial wood (pulp and paper industries), what eventually leads to structural changes in wood supply. That can be a key fact for the wood producers in the near future. Mainly the segment of coniferous sawlogs may be affected by the availability of wood in the future. Slovak forests have various terrain conditions and the current state in the area of harvesting and transportation technologies does not allow effective harvest of the timber from the forest with high percentage of slope. More than $50 \%$ of forests in Slovakia is in some degree of nature protection or in NATURA protection. $32.5 \%$ from the total forest area are forests for special purposes and protection forests. There are also other specific factors which affect timber trade in Slovakia. The market area is deformed by one dominant subject $(50 \%$ of managed forests in Slovakia) and all small subjects must adapt the price strategy to the dominant subject. This dominant subject is partially influenced and confronted with the interests from the side the political parties.

Analysis of the price developments in the selected countries confirmed that all global factors reflected the price level trends approximately equally in all countries; however, the price levels for every country are different. Local impacts, the structure of wood processors and specific approach to the timber trade in Slovakia influence the structure of delivered assortments 
substantially, and there is also space for better recovering of harvested wood. It is also confirmed by the volume decrease in the wood of the finest quality classes for the last 10 years in Slovakia.

Moreover, it is necessary to modify current legislation or to create new legislation in this area; however, in Slovakia there is still unwillingness to enhance the current situation. The wood-market problem solution can be based on following recommendations:

- To monitor development of timber market in the European and world countries regularly, to elaborate marketing analyses of timber trade regularly;

- To review system of positive and negative motivation of responsible employees and to review fixed and variable portion of quarterly paid supplements to wages, both based on the participation of individual work places;

- To sign business contracts, to secure reassessment of prices quarterly; to pay appropriate attention to the formal preparation of business contracts.

In the future, it will be necessary to concentrate on the new sectors interesting for forestry activities (carbon sequestration, carbon trade, renewable energy resources). For the wood processors it will be necessary to concentrate on developing the process of new products based on wood and investing in technology (Němec et al., 2014).

\section{Acknowledgments}

The research presented in this paper was financed jointly by the Cultural and Educational Grant Agency of the Ministry of Education, Science, Research and Sport of the Slovak Republic (Project No. 012-TUZ-
4/2014 - E-learning educational modules for processing of incidental fellings. Project No. 003TU Z-4/2015 - Development of Conceptual thinking at technical universities).

\section{References}

Anonymous. (2015). Green report, years 2005 - 2015, Ministry of Agriculture and Rural development of the Slovak Republic (www.mpsr.sk).

Cipra, T. (1986). Analysis of time series with economy applications. SNTL Prague. (In Czech).

Gejdoš, M., Suchomel, J., \& StasiakBetlejewska, R. (2011). Analysis of wood resources and price comparation in Slovakia and selected countries. In: Proceedings of the 4th International Conference Woodworking Techniques, ČZU Prague, 451-460.

Grzegorzewska, E., \& StasiakBetlejewska, R. (2015). The influence of global crisis on financial liquidity and changes in corporate debt of the furniture sector in Poland. Drvna Industrija, 65 (4), 315-322.

Grladinović, T., Oblak, L., \& Hitka, M. (2007). Production management information system in wood processing and furniture manufacture. Drvna Industrija, 58 (3), 2007, 141-146.

Hinsch, Ch., \& Wächter, F. (2014). Why we need 100 percent renewable energies: A Plea for the Energiewende. Serbian Journal of Management, 9 (1), $121-130$.

Holzkurier. (years 2000-2015).

Němec, M., Dado, M., \& Danihelová, Z. (2014). Document A study on occupational noise exposure of sawmill workers. Akustika, 21 (1), 31-34.

Suchomel, J., Gejdoš, M., Ambrušová, L., 
\& Šulek, R. (2012). Analysis of price changes of selected roundwood assortments in some Central Europe countries. Journal of Forest Science, 11, 483-491.

Patráš, I. (2015). Transparency as one of the objectives from National Program the Wood Utilization Potential in Slovakia Rating as one of the tools for reaching the transparency. In: Current problems in financing of forestry-wood complex. TU Zvolen. (In Slovak).

Simanov, V. (2009). Fuel, or assortment for energy use? Biom.cz [online]. 2009-0727 [cit. 2011-06-20]. Available at: $<$ http://biom.cz/cz/odborne-clanky/palivon e b o - s ortimenty-uzit kove hodrivi?sel_ids=1\&ids[x63eb9e2d85f315a7d7f aeed949f0fd0a]=1>. (In Czech)

Suchomel, J., \& Gejdoš, M. (2009). Forest harvesting and transportation technologies: part assortments of raw-wood and commodity expertising in Forestry. TU Zvolen.

Suchomel, J., \& Gejdoš, M. (2008). Development analysis of technical onditions and prices of raw-wood assortments. TU Zvolen. (In Slovak).

Teplická, K., Čulková, K., \& Železník, O. (2015). Application of bayess principle optimum - Optimization model for managerial decision and continual improvement. Polish Journal of Management Studies, 12 (2), 170-179.

\section{Web references:}

www.nbs.sk

www.cnb.cz

www.czso.cz

www.forestportal.sk 